\title{
Digitalization in the Community-based Tourism Development in Peripheral Areas: A Case Study of Sumbermanjing Wetan Village, Malang Regency
}

\author{
Ayu Dwidyah Rini
}

Universitas Trilogi, Jakarta

\begin{abstract}
The paradigm of digital-based peripheral area tourism development is carried out within a broader development of technology and communication in Indonesia. This is done as a way to reduce the level of disparity between the city and the peripheral region. This study examines the paradigm of local communities related to digital-based tourism development. This digital-based tourism development is illustrated through the case of communitybased tourism in the Sumbermanjing Wetan area of Malang Regency. This article shows that community participation in tourism is classified into three forms of local participation. First, digital-based tourism can be solutions for tourism development in the Sumbermanjing Wetan region. Second, the community also understand the digitalization of tourism as an effort to alleviate poverty and improve the welfare of local communities. Third, digital-based tourism can be the strategy for improving the quality of life of the Sumbermanjing Wetan community.
\end{abstract}

Key words: community-based tourism, peripheral area, gua cina beach and local economy

\section{Introduction}

Effective collaboration between existing resources, community, and government create a healthy and sustainable regional economy. The government, as a regulator, plays a strategic role in seeking broad opportunities for local people to participate fully in every economic activity, one of which is the tourism sector.

Indonesian Statistics Agency
Indonesia. The number of foreign tourists coming to Indonesia before 2015 is always under 10 million people. International tourist visits then surged above 10 million in the following period. Foreign tourist arrivals in 2018 grew by $12.6 \%$ compared to 2017, which amounted to seven million visits. Overseas tourist growth exceeds neighboring countries such as Malaysia and Singapore. Even in 2018, Malaysia experienced negative growth in bringing in foreign tourists.

shows a rapid increase in tourist visits to 
However, the interest of foreign tourists to stay longer in Indonesia is still low. This is indicated by the relatively short duration of tourist visits. Indonesian Statistics Agency (2019) also recorded the average length of stay of foreign tourists in Indonesia is 2.81 days in Bali Province, 2.42 days in Papua Province, and 2.33 days in Southeast Sulawesi Province, while the shortest average length of stay of guests occurred at 1.25 days in Central Java Province. The numbers of occupants of the hotel rooms in Indonesia decreased in December 2018. The most significant number of decreases occurred in four islands: (1) Sulawesi Island, namely Central Sulawesi Province at 14.38 points, (2) Sumatra Island consisting of Aceh Province 14.37 points and North Sumatra Province at 14.31 points. (3) Papua Island decreased by 12.80 points in West Papua. (4) Java Island decreased in three provinces, namely Central Java province by 4.23 points, DI Yogyakarta Province by 2.01 points and East Java Province by 1.73 points. This shows that efforts to improve equity and improve the performance of tourist destinations other than Bali still need to be adjusted.

The above conditions show the government's lack of attention to peripheral tourism. Okech et al. (2012) study on Kenya show that the government has done very little to boost rural tourism and justified by lack of tourism offices in various provinces. Thus, the role of government is enormous in developing peripheral tourism areas.
The peripheral region can be defined as an area far from the population and economic centers, travel to them requires time and costly. Peripheral tourism development is expected to increase value-added peripheral area and triggering peripheral region development process.

Peripheral tourism is part of the development strategy of the periphery. Peripheral tourism can be used as the choice of tourist destinations to extend the length of stay of tourists. Besides, the development of peripheral tourism is also expected to encourage the development of the local economy by utilizing the momentum of increased tourist visits. The results of the Probst et al. (2013) study on the Alpine area show that the development of peripheral regions is very instrumental in maintaining economic sustainability in the region. The development strategy must be oriented towards a unique experience for tourists. A preliminary study on the Mediterranean region in Turkey shows that people in the region did not feel that they were competing with the main tourism area (Seckelmann, 2002; Burak et al, 2004). This has led to differences in behavior between communities in the coastal zone and communities in the main tourist destinations.

Research on peripheral area tourism in Indonesia is still rare. Lew (2011) explored the Indonesian peripheral region in Manado and Lembeh straits in Indonesia and stated that tourism in the area was still disguised and had not yet 
joined the global tourism network. Primadany et al. (2013) conducted a study tour in Nganjuk, Indonesia and showed that optimizing regional tourism development faced obstacles in the lack of funds for the development of facilities and infrastructure to support tourism activities. Khotimah et al. (2017) in a study related to the study of Trowulan cultural tourism in Mojokerto, Indonesia explained that limited funds, limited promotion and supporting facilities and infrastructure for tourism activities were obstacles in developing cultural tourism sites. Therefore, the pattern of setting up tourist destinations is needed in optimizing peripheral areas. Local Government, as the leading sector has a strategic role in developing the facilities and infrastructure needed.

Tourism 4.0, in its development also became a significant concern in developing peripheral tourism areas in Indonesia. The results of the study conducted by Hakim (2018) related to the rise of cyberculture in the tourism sector indicates a significant change in tourism ecosystems, where the strategy of developing tourist destinations and tourist attraction will be influenced by digital information developed and obtained. This phenomenon explains that the era of tourism 4.0 is an excellent opportunity for the development of tourism, especially the peripheral region.

However, technology and information development in tourism 4.0 is still hampered by the lack of supporting infrastructure in the peripheral region.
Sumbermanjing Wetan are faced with communication inconsistencies that are still concentrated in the core region; this harm tourism destinations in the peripheral region. Digitalization of the tourism sector has so far been built downstream, this has led to the promotion of peripheral tourism areas that have not been able to be received in full and detailed by tourists. Tourists do not know in detail the accessibility of tourist attractions to interpret tourism products such as cultural attractions, souvenirs, language and customs of the people.

Sumbermaning Wetan is part of peripherally located far from the city center of. Malang. Sumbermanjing Wetan has tourism potential which is a Chinese Cave Beach tour; unfortunately, this is not widely known by the general public. So, that tourism has not been able to increase regional income (Supriadi, 2016). The tourism sector which is located in Sumbermanjing Wetan is seen as not being able to benefit the local community. Tourism development must provide economic, social and cultural benefits to the communities around the destination. Therefore, the community has a role in the development of Sumbermanjing Wetan tourism.

Community-based tourism is an approach in optimizing tourism development, especially in the digital era. Local communities take the initiative to build, own and manage tourism facilities and services directly so that the community is expected to receive direct economic benefits and reduce 
urbanization. Community-based tourism is expected to be an instrument developing tourism digitalization in Sumbermaning Wetan. There are four principles in the development of tourism digitalization, namely: (a) sustainability of potential tourism, (b) the development of local community institution and partnership, (c) digital education in society $(\mathrm{d})$ tourism digitalization strategy plan.

The problem is that there are still a few local people who have the financial ability and expertise in utilizing technology and information in supporting the tourism digitalization. The formulation of the problem in this study is 1) How is the community paradigm related to digital-based tourism development by the Sumbermanjing Wetan Malang area? and 2) How is the application of community-based tourism conducted by the Sumbermanjing Wetan community in managing digital-based regional tourism? This paper finds that tourism digitalization is essential in optimizing the Sumbermanjing Wetan tourism sector. The tourism sector is believed to be able to improve the welfare of local communities. Communities paradigm related to digitalization is the basis for building a community-based tourism digitalization strategy.

\section{Review of Related Literature}

\section{Supply and Demand in the Tourism} Sector

There is growing literature discussing the relations between tourism and development. They can be divided into two types of approach; First, is supply approach, the supply approach focuses on developing tourist destinations. Second, is the demand approach; the demand approach focuses on tourist spending. Utami et al. (2016) estimated the function of tourism demand in seven tourist destinations in Indonesia. The study shows that tourism prices are the primary determinant of tourist spending.

This phenomenon shows that the factors influencing the development of supporting tourist areas in terms of supply and demand include four main issues. First, attractions of tourist destinations, defined as tourism product components that can attract tourists include natural wealth, developing culture and special events or interests. Potnov and David (1999) in the results of their study regarding the growth of peripheral regions indicate that the attractiveness of migration of an area affects the growth of a sustainable regional population. In this case, the ability of a region to attract new tourists and maintain the number of tourists is a significant factor in developing peripheral areas. Second, accessibility in reaching tourist destinations, these factors include; terminals, ports, airports, systems and transportation routes, travel costs, travel time and frequency of transportation to the destination. Third, amenity, supporting facilities for tourism, including; accommodation, food and beverage, shopping, entertainment and money changers, and tourist information centers. Four, institutions. These can be 
institutional elements, partnerships or supporting organizations in developing and marketing tourism destinations and activities of local communities.

Based on the study of the drivers of the development of the tourist area, a strategic plan is needed in tourism development. The tourism development strategy has implications for three things. First, improvement of existing products. In our case, the potential for peripheral tourism is increased through the development of potential areas that will be used as tourist destinations. Second, identification of opportunities in determining new markets. In this case, internal and external factors in the peripheral region determine the tourism development strategy. Third, the existence of the local industry as a priority in the long term.

Regional and local policies are expected to be oriented towards the growth of the peripheral tourism sector. Policy orientation refers to six principles of developing the peripheral tourism sector. First, tourism development strategies are oriented towards improving quality growth. The approach aims to develop potential locations and the quality of tourist area attractions. Secondly, digital-based promotional activities are part of the development of tourism areas. Third, cooperation in the form of public and private partnerships is a form of interaction between stakeholders. Fourth, tourism development at the destination level must be actualized in regional and local policy planning. Fifth, peripheral tourism areas that are developed must be able to stimulate business in supporting regional development. This is supported by regional and local policies in accelerating the formation of peripheral tourist areas. Sixth, business activities with government and non-profit attractions can be integrated through system. This is written in the form of the realization of the attraction business planning policy (natural and cultural) which is supported by travel and accommodation business.

\section{Peripheral tourism}

Peripheral tourism can be defined as tourism in an area that is not a major destination. Peripheral tourism can be in a less strategic area (Chaperon \& Bramwell, 2013). The relationship between core and peripheral tourist destinations has been discussed in various previous studies. Kurnianingsih et al. (2014) explain that as the relationship between rural and urban areas, exploitation can be carried out by the core region to the peripheral region. Core tourism areas usually have a higher economic level, high innovation and are equipped with infrastructure and amenities. Widodo and Lupiyanto (2011) explain that the lack of attention to tourism development in the periphery of the region precisely in the Bantul Regency of Yogyakarta had an impact on the waning of the region's superior potential and environmental degradation. This phenomenon shows that development in the peripheral area are needed in improving people's welfare, optimizing its potential, preserving the environment, 
strengthening community participation in developing peripheral tourism destinations.

Peripheral tourism activities are believed to have an impact on the economy of Bukit Tinggi City. The activities also create multipliers effects on the hospitality industry with the increasing number of tourists around tourism objects (Arianti, 2016). This phenomenon implies that Indonesia's tourism development strategy is oriented to increase the socio-economic sustainability of peripheral tourism areas. This has implications for the reallocation of the Government's financial budget in encouraging the acceleration of peripheral tourism development. The strategy for planning peripheral area development can be realized in four strategic steps, including; (a) establishment of tourist destination clusters based on evolving geographical, economic, social and cultural characteristics, (b) financial concentration of the central and regional governments on potential area development, (c) active promotion by involving the private and public, and (d) land use limitation regulations in the core region (Potnov, 1999).

\section{Community-Based Tourism}

Community-Based Tourism is defined into three perspectives, among others; 1) form of tourism that provide space for the community to actively participate in planning, developing and controlling tourism development, 2) form of tourism that benefit the community both actively and passively involved in tourism businesses, 3) tourism strategies oriented to political empowerment and democratization, and 4) a form of tourism that makes the people of rural areas prosper. Thus community-based tourism is an approach to tourism development that is oriented towards local communities (both those who are directly involved and not involved in the tourism industry). Community-based tourism provides access in planning, building and developing tourism based on community empowerment and equitable distribution of benefits to the community.

Community-based tourism has the following basic principles: a) recognizing, supporting and developing community ownership in the tourism industry, b) including community members in the planning stage, c) developing community pride, d) developing community quality of life, e) guaranteeing environmental sustainability, f) maintaining the uniqueness of character and culture in the local area, g) developing learning of cultural exchange in the community, $h$ ) tolerance of cultural differences and human dignity, i) distributing benefits equitably to community members, j) playing a role in determining income distribution processes (Suansri, 2003). These basic principles are the essence of implementing development in local communities. Community-based tourism implements ten basic principles by establishing a balanced relationship between local communities and tourists in terms of community ownership status, fair distribution of benefits, mutual respect, 
and awareness in protecting the environment.

Community-based tourism is developed in the community by containing three dimensions, including 1) economic dimension, explained through three indicators, among others; funds available for community development, employment in the tourism sector, local people's income generated from the tourism sector; 2) social dimensions explained through four indicators, among others; the quality of life of the community, the emergence of pride in the community, the distribution of roles fairly in the community, the formation of cooperative relationships in the community; 3) cultural and environmental dimensions are explained through four indicators, among others; community initiation for mutual respect for different cultures, the creation of close ties of society with local culture, concern for environmental sustainability and the existence of community rights in managing natural resources. Therefore, the local government, in this case, plays a role in assisting the community so that the objectives of community-based tourism can be carried out. Community-based tourism is an approach oriented to community participation to achieve the goal of equitable distribution of benefits, poverty alleviation and efforts to preserve the culture and the environment. Community-based tourism also has implications for strengthening local institutions, where the development of tourism businesses in rural areas is difficult to regulate by existing institutions.
Therefore, community-based tourism is an institutional approach involving community members. Community-based tourism also has implications for the creation of strong relationships at regional and national levels. Community-based tourism bridges local communities with national or international markets so that domestic and foreign tourists can enjoy peripheral tourism areas.

\section{Digitizing Peripheral Region Tourism}

Digitalization of tourism has been built up in the downstream region or the main destination so that attention to peripheral tourist destinations has not been optimal. The digital transformation of the tourism sector has resulted in major changes in the world. Foreign tourists who visit Indonesia as much as fifty percent consist of millennial tourists with an average age of 15-23 years. The digital era has also changed tourist behavior to be more independent and individual. For example, Chinese tourists who were initially been famous for group tourism are now more into individual tourism. This is the right moment for the development of Indonesian tourism. Human resources are the main key in building and developing digital tourism. Therefore, the paradigm of local communities related to tourism digitalization is the main factor in efforts to understand and build solutions to the problems faced by peripheral regions.

The paradigm of digital-based peripheral area tourism development is carried out amid the development of technology and communication. This is 
done as a form of reducing the level of disparity between the city and the peripheral region. The peripheral community also needs accurate information in determining the right solution in building the quality of the tourism area and the participation of the community. The results of Arifin (2017) study of tourism digitalization explain that digital-based tourism can provide a positive image for regional tourism and human development. Hence, a change in the paradigm of peripheral tourism development from traditionally based into digital-based needs to be done. The strategies that can be carried out in building a digital-based peripheral tourism development paradigm are as follows (Badri, 2016). First, building the website of village areas with desa.id domains. Second, migration of open source technology. Third, developing peripheral tourism partners with various online tourism service providers. Fourth, building regional interconnections that support the development of the potential of local tourist destinations.

\section{Discussion}

\section{A paradigm of Digital-Based Peripheral Tourism Development}

Gua Cina is beach tourism in Sumbermanjing Wetan region that has developed from year to year, but in its development, there are still many tourism potentials that have not been optimally worked on. Accommodation and transportation facilities are still an obstacle for several tourists who want to visit Gua Cina. This is certainly a challenge in tourism digitalization. Digitalization is expected to bring positive changes to the improvement of the Sumbermanjing Wetan area.

The community also understand the digitalization of tourism as an effort to alleviate poverty and improve the welfare of local communities. People put high hopes in developing digital-based tourism, where the region will grow and economic productivity increase. The tourism development of Gua Cina in Malang Regency is expected to be able to absorb large numbers of workers every year so that it will have an impact on the welfare of the Sumbermanjing Wetan community.

The strategy for improving the quality of life of the Sumbermanjing Wetan community is through digitalization. Digitalization can encourage infrastructure improvements in the telecommunications and internet, transportation and information sectors carried out by the Regional Government. The paradigm of the digital-based development of the Gua Cina beach can be identified as a form of positive public trust in economic and social improvements.

Tourism digitalization in the tourism industry's supply and demand perspective is a medium in integrating the behavior of tourism industry players and tourists. Gua Cina beach still has potential problems, which are identified by three factors. First is accessibility. Public transportation facilities leading to coastal tourism objects are still very minimal. The road to Gua Cina Beach is still very 
limited in lighting, thus hampering tourists' interest. Second is amenities. Promotion of tourism objects is still the biggest problem because there is no travel agent incorporated in the promotion of tourism objects. Tourism activities, including the creation of souvenirs developed by local people, do not exist. This has implications for the lack of attractions that can be displayed to tourists. there are inadequate supporting facilities such as ATMs, lodging and health posts that are not yet available. Telephone and internet networks are not yet available.

The above phenomenon is obstacles in the realization of digitalization of the Gua Cina Beach tourist destination. Therefore, it is necessary to strengthen the communication and information technology infrastructure that is maximally integrated. Information, communication, and technology available make it easier for tourism industry players to access data such as destination promotion, destination development, tourism industry growth, and tourism human resource needs. The central government has a role in supporting digital transformation so that the changes are in the right direction. Regulations determined by the government will help businesses and the local governments in carrying out integrated digital transformation.

The paradigm of the digital-based development of the Gua Cina tourism built by local communities is carried out in several stages. The first stage is to develop peripheral tourism information networks by creating integrated regional tourism websites on Malang Regency website. The second stage is to develop the attractiveness of tourist destinations including local cultural attractions, local crafts such as souvenirs and culinary snacks that are promoted online. The third stage is to improve online promotion, not only through Instagram, Twitter and websites but also various other digital platforms. The fourth stage is to establish cooperation and partnerships with online travel agents, governments, universities and community social institutions.

\section{Development of Peripheral Tourism Community Based Tourism}

Community-based tourism is a form of approach in increasing community participation in regional tourism. The perspective of community participation in tourism is classified into two forms of local participation, first is community participation in the decisionmaking process. With the participation of local people, the benefits of tourism activities can be received by the local community. Second is the involvement in the process of determining and distributing profits derived from local tourism development. The community is directed in the process of identifying needs, interests, and commitment to planning tourism to improve the welfare of the local community. Thus, the community is given the full right to manage resources and allocate potential resources by regional characteristics. The 
local people can get benefits according to the use of resources.

Community-based tourism can be developed using three approaches. The first is spontaneous community participation (spontaneous participation). Spontaneous participation is defined as community efforts to initiate ideas and implement the ideas together. Thus, the planning and tactics implemented are from the community (bottom-up). This is proven in the stages of building community commitment, where the Sumbermanjing Wetan Village community is aware of tourism opportunities that can be developed and are committed to developing them. Spontaneous participation is also implemented in the decision-making process, where communities are involved as decision-makers in shaping the institutions and management of existing tourist attractions. The second is the establishment of tourism village institutions, involving village officials, district governments, the private sector, and local communities following their roles and functions in developing Sumbermanjing Wetan tourism potential. The institution is needed as an effort to optimize the tourism performance of Sumbermanjing Wetan. Therefore, the involvement of community members in the institutional element is very necessary. It aims to regulate relations between residents, resources, and visitors. Institutions can be strengthened by training and developing community skills with the essential soft skills (including management, communication, entrepreneurial experience, and organizational experience).

The third is diversification of business products. Local communities are encouraged to initiate in creating potential tourism business products such as making souvenirs, marine tourism education, homestays, and culinary businesses. The community is not only directed to manage the tourist attraction but also creates other business products that are interrelated with each other. Thus, the variety of business products that are raised, can provide many choices for tourists to enjoy a tourist village product. The community involved can feel and experience the economic benefits of China Cave tourism activities.

\section{Conclusion}

Digital-based tourism has indeed provided solutions for tourism development in the Sumbermanjing Wetan region. The community also understand digitalization of tourism as an effort to alleviate poverty and improve the welfare of local communities. The strategy for improving the quality of life of the Sumbermanjing Wetan community. Digitalization provides positive trust in the peripheral community to get a better life.

Community-based tourism can be developed through three approaches. First, community-based tourism can be developed through mobilizing spontaneous participation of local communities. This is an effort to build community awareness and commitment 
to tourism opportunities that can be developed and encourage the community in making decisions in the process of establishing tourism village institutions. Second, community-based tourism can be achieved by establishing tourism village institutions by involving Sumbermanjing Wetan community members as administrators. Institutions function in regulating relations between residents, resources, and visitors. Therefore, institutional strengthening is done by training and developing community skills with the necessary soft skills. Lastly, community-based tourism can be developed through the creation of a diversification of the potential of tourism products. Diverse business products can provide many choices for tourists to enjoy a tourist village product. Thus, the people involved can feel and experience the economic benefits of Gua Cina tourism activities.

\section{About the Author}

Ayu Dwidyah Rini was born in Jombang, East Java. She had been studied Master of Economic Education at State of Malang University. Prior to working at State of Malang University, Universitas Ciputra, East Java, and in 2017 until now she became a lecturer in economics at Universitas Trilogi.

\section{References}

Arifin, S. (2017). Digitalisasi Pariwisata Madura. Jurnal Komunikasi, 11(1), 53-60. DOI: http://dx.doi.org/10.21107/ilkom.v1 $\underline{1 \mathrm{i} 1.2835}$
Arianti, D. (2016). Pengaruh Sektor Pariwisata Terhadap Perekonomian dan Keruangan Kota Bukittinggi (Pendekatan Analisis Input Output). Jurnal Wilayah dan Lingkungan, 12(4), 347360.

DOI:

https://doi.org/10.14710/pwk.v12i4. $\underline{13502}$

Badri, M. (2016). Pembangunan Pedesaan Berbasis Teknologi Informasi dan Komunikasi (Studi pada Gerakan Desa Membangun). Jurnal RISALAH， 27(1)， 62-73. DOI: 10.24014/jdr.v27i2.2514

Badan Pusat Statistik. (2019). Perkembangan Pariwisata dan Transportasi Nasional Desember 2018. Berita Resmi Statistik. 12(2), 1 16.

Burak, S., Dogan, E., \& Gazioglu, C. (2004). Impact of urbanization and tourism on coastal environment. Ocean $\mathcal{E}$ Coastal Management, 47(9-10), 515-527.

Chaperon, S., \& Bramwell, B. (2013). Dependency and Agency in Periheral Tourism Development. Annals of Tourism Research, Retrieved August 17, 2019, from https://www.researchgate.net/publ ication/256987123

Hakim, I. N. (2018). Pergeseran Budaya Siber \& Visual di Sektor Pariwisata Indonesia. In Seminar Nasional Seni dan Desain UNESA.

Kurnianingsih, N. A., \& Rudiarto, I. (2014). 
Analisis Transformasi Wilayah Peri-Urban pada Aspek Fisik dan Sosial Ekonomi (Kecamatan Kartasura). Jurnal Pembangunan Wilayah \& Kota, 10(3), 265.

Khotimah, K., Wilopo., \& Hakim, L. (2017). Strategi Pengembangan Destinasi Pariwisata Budaya. Jurnal Administrasi Bisnis, 41(1), 56-65.

Lew, A.A. (2011). "Adjectival, Specialty and Niche Tourisms", Retrieved August 17, 2019 from http://alew.hubpages.com/hub/Adj ectival-Tourism.

Okech Roselyne., Morteza Haghiri., \& Babu P. George. (2012). Rural Tourism As A Sustainable Development Alternative: An Analysis with Special Reference to Luanda Kenya. Cultur Revista de Cultura e Turismo, 6(3), 36 -54.

Potnov, A., \& Pearlmutter, D. (1999). Sustainable Urban Growth in Peripheral Areas. Elsevier, 52(4), 239-308.

Primadany, R., Mardiyono., \& Riyanto. (2013). Analisis Strategi Pengembangan Pariwisata Daerah (Studi Kasus Dinas Kebudayaan dan Pariwisata Daerah Kabupaten Nganjuk). Jurnal Administrasi Publik, 1(4), 135-143.

Probst, L., Donnini, M., Probst, A., Frondini, F., Marchesini, I., \& Guzzetti, F. (2013). The contribution of weathering of the main Alpine rivers on the global carbon cycle. Geophysical Research Abstracts, 15, 71-85. Retrieved August 17, 2019, from https://www.researchgate.net/publ ication/258777106

Seckelmann, A. (2002). Domestic tourism-a chance for regional development in Turkey?. Tourism Management, 23(1), 85-92.

Suansri, P. (2003). Community based tourism handbook. Bangkok: Responsible Ecological Social Tour-REST.

Supriadi, B. (2016). Pengembangan Ekowisata Pantai sebagai Diversifikasi Mata Pencaharian. Jurnal Pesona, 18(1), 1-20.

Utami, R. C., \& Hartono, D. (2016). Analisis Daya saing Harga Pariwisata Indonesia: Pendekatan Elastisitas Permintaan. Jurnal Kepariwisataan Indonesia: Jurnal Penelitian dan Pengembangan Kepariwisataan Indonesia, 11(1), 93118.

Widodo. B, dan R. Lupyanto. (2011). Pengembangan Kawasan Pinggiran Kota dan Permasalahan Lingkungan di Kampung Seni Nitiprayan Bantul. Jurnal Sains dan Teknologi Lingkungan, 3(1), 31 - 51. 